\title{
The surface-piercing salt domes in the Ghaba Salt Basin (Oman): A comparison to the intra-salt hydrocarbon play of the Ara Group
}

\author{
L. Reuning (1), J. Schoenherr (2), A. Heimann (1), J. L. Urai (1), R. Littke (1), P. A. Kukla (1), and Z. Rawahi (3) \\ (1) RWTH Aachen University, Geological Institute, Aachen, Germany (reuning@geol.rwth-aachen.de), (2) ExxonMobil \\ Production Germany GmbH, Riethorst 12, 30659 Hannover, Germany, (3) Petroleum Development Oman LLC, P.O. Box 81, \\ P.C. 113, Muscat, Sultanate of Oman
}

In the South Oman Salt Basin the Ara carbonates form an extensively cored, deeply buried intra-salt hydrocarbon play. Six surface-piercing salt domes in the Ghaba Salt Basin (North Oman) provide the only outcrop equivalents for carbonates and evaporites of the Ediacaran-Early Cambrian Ara Group (uppermost Huqf Supergroup). Based on fieldwork, satellite imaging and isotope analysis it is concluded that most of the carbonate bodies (so-called stringers) in the Ghaba salt domes are time equivalent to the stratigraphically uppermost stringer intervals in the South Oman Salt Basin (A5-A6). Maturity analyses demonstrate that the carbonate stringers in the salt domes were transported with the rising Ara salt from burial depths of $\sim 6$ to $10 \mathrm{~km}$ to the surface. Petrographic and stable isotope data show that their diagenetic evolution during shallow and deep burial was very similar to the Ara carbonate stringer play in the SOSB. However, during the retrograde pathway of salt diapir evolution, the carbonate stringers were exposed to strong deformation in the diapir stem and diagenetic alterations related to dedolomitisation. As the salt domes contain facies that are in all aspects identical to the deeply buried Ara play in the South Oman Salt Basin, this study provides substantial additional information for hydrocarbon exploration in South Oman. In addition, our work has implications for the hydrocarbon prospectivity of the Ghaba Salt Basin and possibly of other Ediacaran-Early Cambrian evaporite basins in the Middle East such as for the time-equivalent 'Hormuz' salt basins. 